Vol. 4, No. 1, 2018

\author{
Mykhaylo Student ${ }^{1}$, Hanna Pokhmurska ${ }^{2}$, Khrystyna Zadorozhna ${ }^{3}$, \\ Andrii Dzyubyk ${ }^{4}$, Ivan Khomych ${ }^{5}$ \\ ${ }^{1}$ Department of Superficial Strengthening of Structural Materials, Karpenko Physico-Mechanical institute of the \\ NAS of Ukraine, 5, Naukova Str., Lviv, Ukraine, E-mail: student-m-m@ipm.lviv.ua \\ ${ }^{2}$ Department of Welding Manufacture, Diagnostics and Restoration of Metal Structures, Lviv Polytechnic \\ National University, 12, S. Bandera Str., Lviv, Ukraine, E-mail: zvdv@ukr.net \\ ${ }^{3}$ Department of Superficial Strengthening of Structural Materials, Karpenko Physico-Mechanical institute of the \\ NAS of Ukraine, 5, Naukova Str., Lviv, Ukraine, E-mail: kh-zadorozhna@nas.gov.ua \\ ${ }^{4}$ Department of Welding Manufacture, Diagnostics and Restoration of Metal Structures, Lviv Polytechnic \\ National University, 125, S. Bandera Str., Lviv, Ukraine, E-mail: andrii.r.dziubyk@lpnu.ua \\ ${ }^{5}$ Department of Welding Manufacture, Diagnostics and Restoration of Metal Structures, Lviv Polytechnic \\ National University, 12, S. Bandera Str., Lviv, Ukraine, E-mail: ivankhomych_@ukr.net
}

\title{
STRUCTURE AND WEAR RESISTANCE OF ALUMINIUM ALLOYS COATED WITH SURFACE LAYER LASER-MODIFIED BY SILICON CARBIDE
}

Received: October 25, 2017 / Revised: March 13, 2018 / Accepted: June 26, 2018

(C) Student M., Pokhmurska H., Zadorozhna K., Dzyubyk A., Khomych I., 2018

Abstract. Modern approaches to ensuring the necessary characteristics of surface of a material with the aim to improve economic and technological characteristics of the structures are considered in this paper. It is shown that aluminium alloys gain wide application in industry. Nevertheless, surface characteristics of materials are insufficiently good for their use in structures which operate under abrasive wearing and boundary friction.

The use of the method of surface modification by a concentrated light-beam of energy is of prospect. Analysis of literature data indicates that in the course of laser-modification of surface of an aluminium alloy it is possible to form a material whose operational characteristics are higher than those of the material in its initial state. However, herewith it is important to quantitively estimate properties of the obtained composite layer on the surface of the article as well as to estimate the distinction between the layer and the main metal.

The microstructure of laser-modified composite layers of aluminium alloys which had been formed by means of direct blow-in of SiC powder into the melted by laser radiation zone of surface has been investigated.

Laser reinforcement of surfaces of aluminium alloys by $\mathrm{SiC}$ particles causes pronounced inhomogeneity of structure of surface layers of alloys. It has been shown that preliminary heating of specimens in the course of their laser-treatment increases the depth of the modified layer over the whole zone of treatment and improves the uniformity of distribution of reinforcing $\mathrm{SiC}$ particles; however, because of turbulence in the melt there is observed some non-uniformity of distribution of $\mathrm{SiC}$ particles in the modified layer.

It is found that in the interaction of $\mathrm{Al}$ melt with $\mathrm{SiC}$ particles there forms plates of $\mathrm{Al}_{4} \mathrm{C}_{3}$ carbide at the interface, these plates grow mainly co-axially to the orientations of $\mathrm{SiC}$ crystals in the direction to the melt. Besides, in the matrix there takes place partial dissolution of $\mathrm{SiC}$ with formation of needle-shaped $\mathrm{Al}_{4} \mathrm{C}_{3}$ carbides.

During the modification of surfaces of these alloys, in the case of increased concentration of silicium in the melt there is also observed inclusion of pure silicium. Besides, there is also possible the diffusion of aluminium into thin near-surface layer of silicium carbide, the layer separates from $\mathrm{SiC}$ crystal (phenomenon of ply separation) when the concentration of aluminium reaches a value of $3-5 \%$. 
It is established that the abrasive wear resistance of the non-modified AD35 alloy, which is determined according to the method of rigid abrasive wheel, is by $30-45 \%$ higher than that $\mathrm{B} 95$ alloy. In this case, the deterioration (wear-and-tear) proceeds according to the following two mechanisms: (1) by cutting and (2) by adhesive grafting between the abrasive wheel and the aluminium alloy by tearing out alloy particles from the surface.

Optimal regimes of laser reinforcement of surfaces of aluminium alloy by means of fine $\mathrm{SiC}$ particles have been determined in this paper; this enabled us to increase 40-70 times the wear resistance of aluminium alloys in comparison with non-modified alloys when they are subjected to friction by rigidly fixed abrasive particles. The same reinforcement almost two times increases the wear resistance in dry reversive friction, and it increases the wear resistance only by $10-25 \%$ in wearing by loose abrasive particles.

Keywords: surface characteristics, aluminium alloy, composite layer, radiation zone, diffusion, inhomogeneity, wear resistance, friction, laser reinforcement.

\section{Introduction and problem statement}

Modern technological processes of restoration and strengthening of surface layers are aimed at ensuring and obtaining their special characteristics for articles which are made of ordinary structural materials [1, 2]. With this, there is ensured not only the technological effect from the increase in longevity, but also economic effect from reduction in prime cost of the structure as a whole. This is caused by the reduction in requirements of alloying elements and by more effective preparation and treatment.

It is known that about $30 \%$ of all metals which are annually smelted are consumed for compensation of losses caused by corrosion and wear [1]. Therefore, the development and introduction of modern methods of surface strengthening and of materials for ensuring these development and introduction is of importance [3].

\section{Analysis of modern information sources on the theme of the paper}

Nowadays, aluminium alloys which are of high specific strength and of relatively low cost gain wide use in industry. With this, the surface characteristics of such materials are insufficiently good for their use in structures which operate under the condition of wear and tribe-loads. For ensuring and improving such characteristics, different methods of creation and application of coatings [1,3] ure used. The use of the method of surface modification by a concentrated light beam of energy $[2,4]$ is of prospect. This ensures the obtaining of localized heating to high temperatures only to a given depth with the possibility to additionally introduce another material $[2,5]$. With this, the energy transfer can take place in different external gas media in contactless way $[2,5,6]$. Analysis of data from literature sources indicates that in the course of surface laser-modification of an aluminium alloys it is possible to form a material of higher operational characteristics in comparison with its initial state $[4,7]$. However, with this, it is important to quantitively estimate the properties of the obtained composite layer on the surface of the article and the distinction of the composite layer from the main metal.

\section{Aim and task of the investigation}

The aim and the task of these investigations consist in the increase of wear resistance of surface of an aluminium alloy. With this, there is used the method of surface laser-modification by solid particles of Si carbide, the method consists in direct blow-in of solid particles into a zone of material where the material is melted by laser beam (Fig. 1). It is necessary to carry out investigations of the tribological properties and wear resistance of the obtained layers. For surface reinforcement, there were used B95 and AD35 aluminium alloys (Table 1) and powder of SiC whose dispersivity was 20-40 $\mu \mathrm{m}$, hardness of $2600 \mathrm{HV}$, and melting point of $2760{ }^{\circ} \mathrm{C}$. Surfaces of specimens were treated by means of a repeatedly moving laser beam, whose power was $50 \mathrm{~kW}$; the distance from the surfaces of the samples to the focus of laser beam was of $1.5-2 \mathrm{~mm}$, the speed of the laser beam was of $100-150 \mathrm{~cm} / \mathrm{min}$, and the overlap factor of the tracks was of $50 \%$. 


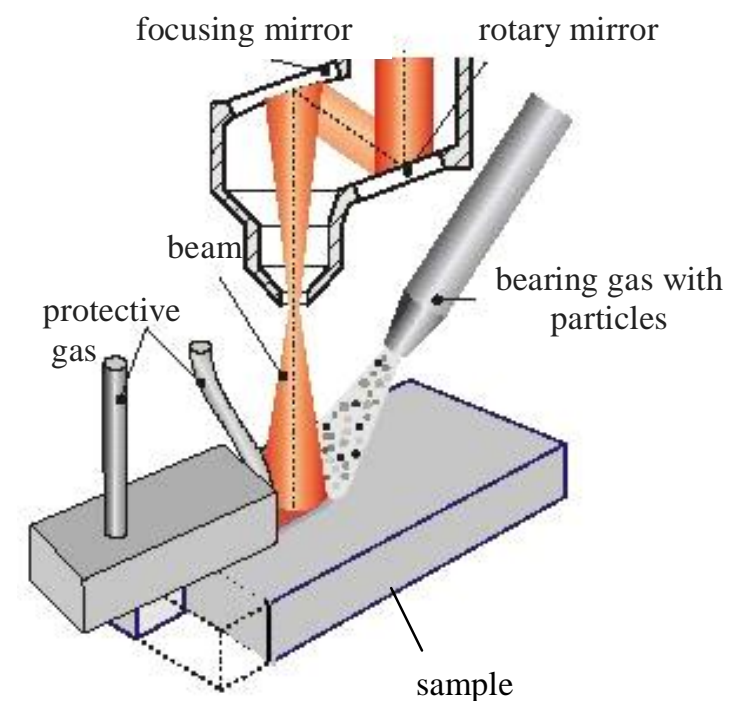

Fig. 1. Formation of coating by means of blow-in powders into zone of laser-fusing of metal surface

Table 1

Chemical composition of AD35 and B95 alloys

\begin{tabular}{|l|c|c|c|c|c|c|c|c|c|}
\hline Element, \% & $\mathrm{Al}$ & $\mathrm{Mg}$ & $\mathrm{Si}$ & $\mathrm{Cr}$ & $\mathrm{Mn}$ & $\mathrm{Ti}$ & $\mathrm{Cu}$ & $\mathrm{Fe}$ & $\mathrm{Zn}$ \\
\hline $\mathrm{AD} 35$ & $95.2-98.3$ & $0.6-1.2$ & $0.7-1.3$ & $\max 0.25$ & $0.4-1$ & $\max 0.1$ & $\max 0.1$ & $\max 0.5$ & $\max 0.2$ \\
\hline B95 & $87.1-91.4$ & $2.1-2.9$ & $\max 0.4$ & $0.18-0.28$ & $\max 0.3$ & $\max 0.2$ & $1.2-2$ & $\max 0.5$ & $5.1-6.1$ \\
\hline
\end{tabular}

Test methods

The determination of wear resistance of the specimens was conducted according to the following method. The wearing by loose abrasive particles was investigated according to suggested in [8,9] techniques. The essence of the method consists in the fact that some dried quartz sand was fed into the zone of friction of a rubber wheel over surface of a specimen. The diameter of the rubber wheel was $50 \mathrm{~mm}$, the rotation frequency $2.1 \mathrm{~s}^{-1}(25$ revolutions $/ \mathrm{min})$. The wheel was pressed to the specimen with he force of $\mathrm{P}=(44.1 \pm 0.25) \mathrm{H}$. the test duration was $5 \mathrm{~min}$.

During the friction of specimens by rigidly fixed abrasive, there was used an abrasive wheel of the diameter of $150 \mathrm{~mm}$, width $8 \mathrm{~mm}$; it was made of CM-2 corundum the size of grains of which was $20 \mu \mathrm{m}$, the rotation frequency was $2.7 \mathrm{~s}^{-1}$ (58 revolutions/min), the load in the zone of linear contact $\mathrm{P}=(14.7 \pm 0.25) \mathrm{H}$ the test duration $30 \mathrm{~min}$.

The wear resistance of the alloys under the condition of dry friction was determined with the use of non-standard techniques; in such techniques a flat working specimen was weared by a wheel counter-body in linear contact. There was used a counter body whose diameter and width of the disc were 40 and $10 \mathrm{~mm}$, respectively; it was made of steel WX15 (C - 0.95-1.05\%; Si - 0.17-0.37\%; Mn - 0.2-0.4\%; $\mathrm{Ni} \leq 0.35 \%$; $\mathrm{Cr}-1.3-1.65 \%)$ bearing steel hardened to the hardness of its working surface of about $60 \mathrm{HRC}$. The value of wear of surface was determined on the basis of mass loss accurate to $\pm 0.0001 \mathrm{~g}$. The working specimens were of the size $30 \times 15 \times 8 \mathrm{~mm}$ with modified under different regimes surfaces of $30 \mathrm{X} 15 \mathrm{~mm}$, which were grinded before their testing. The specimen was pressed to the counter-body with the force $1.5 \mathrm{~kg}$, the speed of friction was $67 \mathrm{~m} / \mathrm{min}$, and the test duration was of 15-30 min.

\section{Results of experiments}

The process of modification of surfaces of aluminium alloys by means of powders of silicide across, oxides, carbides, and other compounds entails considerable technological difficulties because of great difference of their physical properties, that obstruct uniform distribution of powder grains in a pool of melted metal. Besides, it is necessary to take into account the turbulent streams of melted metal, non- 


\section{Mykhaylo Student, Hanna Pokhmurska, Khrystyna Zadorozhna, Andrii Dzyubyk, Ivan Khomych}

uniform distribution of temperature, which causes a gradient of viscosity of the melt, and rapid progress of the process of melting-crystallization of the alloy (Fig. 2). Taking this into consideration, the modificationreinforcement of surfaces of alloys was conducted both at room temperature and under heating the specimens to 100,170 , or $260^{\circ} \mathrm{C}$. The preliminary heating of an alloy reduces the temperature gradient in the melted metal and ensures slow crystallization rate, that would increase the depth of modified layer and improve the uniformity of the distribution of solid particles in it.

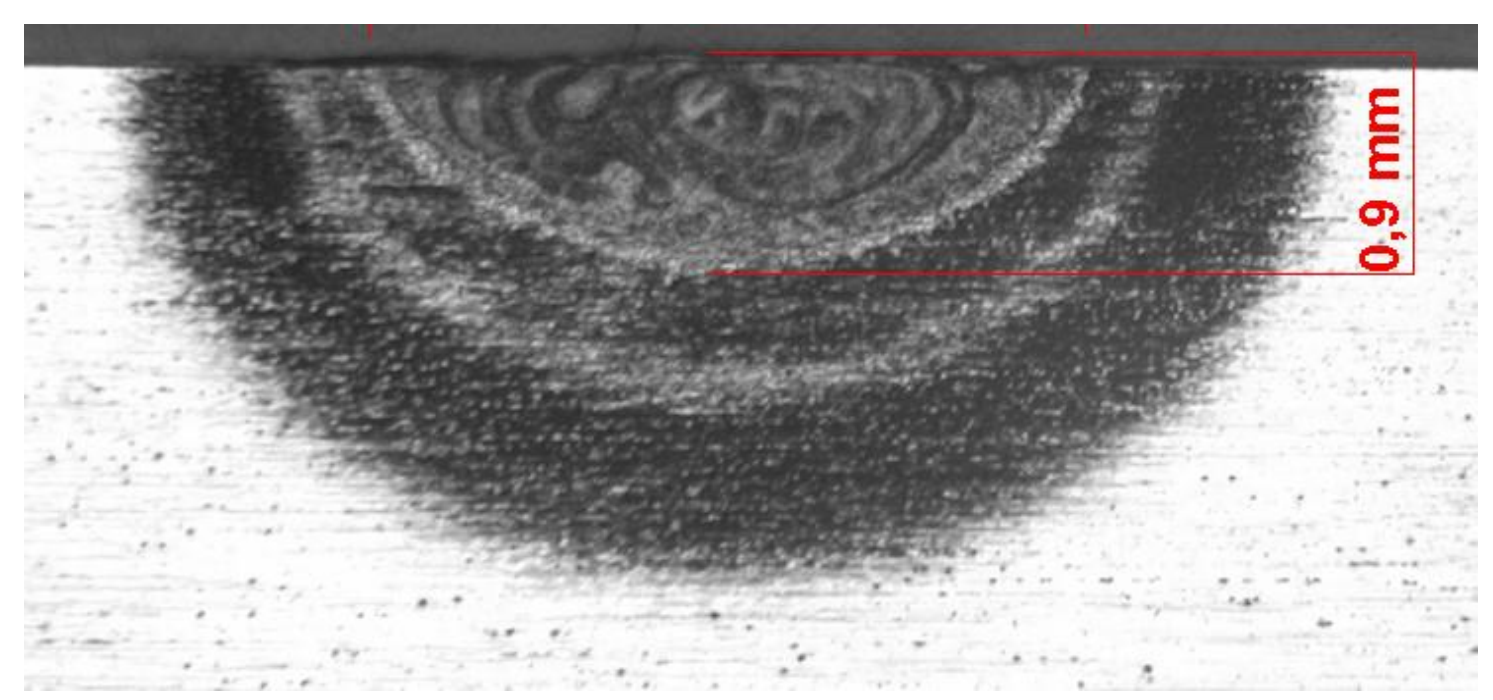

Fig. 2. Non-uniform character of zones of thermal influence and turbulence in zone of fused track of aluminium alloys

Results of the experiments (Fig. 3) have indicated that the modification of surface of preliminarily heated to $260{ }^{\circ} \mathrm{C}$ alloy with the speed of motion of the beam $10 \mathrm{~m} / \mathrm{min}$ ensures penetration of grains of silicium to a depth of 2.6-2.8 mm (Fig. 3, a); this considerably exceeds the depth of the modified layer which is obtained on aluminium alloys without preliminary heating (Fig. 3, $b$ ). In the first case, the number of $\mathrm{SiC}$ grains in remelted layer is considerably greater, and their distribution is more uniform.

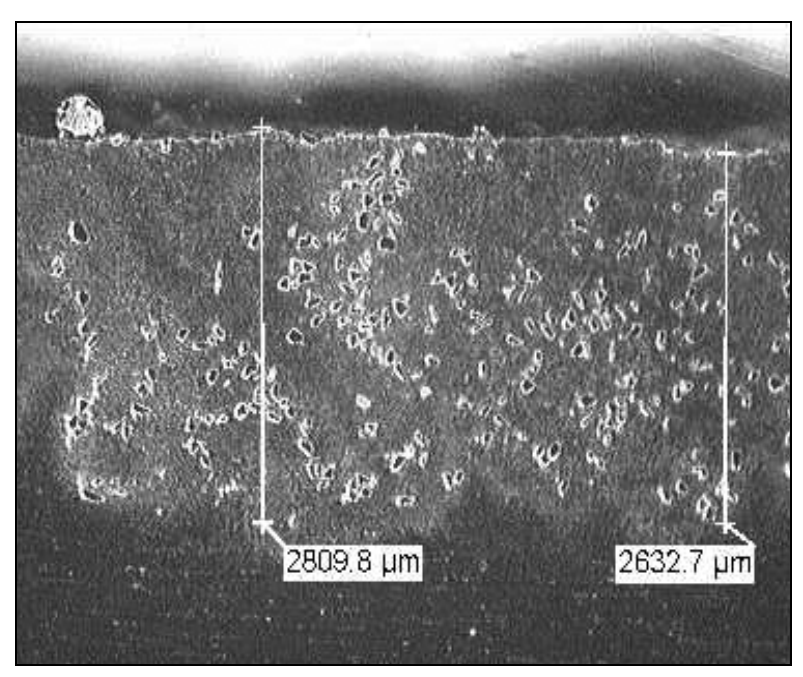

$a$

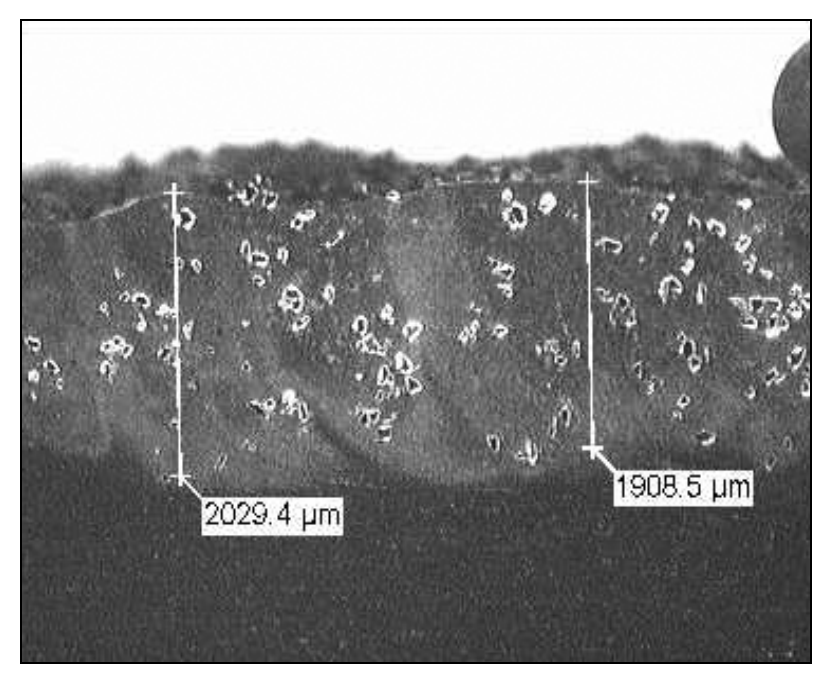

$b$

Fig. 3. Microstructure of modified surface layer of B95 alloy obtained by means of direct reinforcement by SiC particles during treatment by radiation of $\mathrm{Nd}: Y A G$-laser whose power is $1.7 \mathrm{~kW}$ and speed of beam movement $1.0 \mathrm{~m} / \mathrm{min}$ (Heating of specimens in the course of treatment: $260{ }^{\circ} \mathrm{C}(\mathrm{a})$ and $170{ }^{\circ} \mathrm{C}(\mathrm{b})$ )

Metallographic analysis of the laser-reinforced layer indicates that in the reinforcement by means of a mixture of SiC-AlSi powders the melting temperature point considerably decreases, and the modified 
layer can be conventionally divided into two zones: the zone which is closer to the surface, in which particles of $\mathrm{SiC}$ are present, and the second zone, which is situated under the first zone, which does not contain SiC particles. Laser-modification of the surface layer of aluminium alloys proceeds in the way of its local remelting and blowing-in particles of $\mathrm{SiC}$ into it. Due to the fact that the aluminium melt is of high viscosity, and the melt pool exists for $0.1-0.5 \mathrm{~s}, \mathrm{SiC}$ particles do not penetrate to the whole depth of the melted aluminium; and therefore, there emerge two zones of laser-remelt. The microstructure which is at the bottom of the re-melted domain to where $\mathrm{SiC}$ particles have not penetrated, consists of simple grains of the alloys of the size of 50-100 $\mu \mathrm{m}$. The grains contain in themselves great amount of dendrites of a length of about $5 \mu \mathrm{m}$. The longitudinal axes of the dendrite are oriented in radial direction with small amounts of Se and in the interdendride zone.

$\mathrm{SiC}$ particles can be partially dissolved in the course of existence of the melt, and they can form Al4C3-plates in the matrix of the re-melted zone (Fig. 4). The extent of surface dissolving of particles of silicium carbide depends on the temperature of the melt and on the duration of its staying in liquid state.

Therefore, the formation of aluminium carbide can be observed in the whole domain of the re-melted alloy between $\mathrm{SiC}$ particles (Fig. 4) in the case of modifying of preliminarily heated to $170-260{ }^{\circ} \mathrm{C}$ alloy; or only close to surfaces of $\mathrm{SiC}$ particles in the case of laser-modification of the surfaces of non-heated specimens.

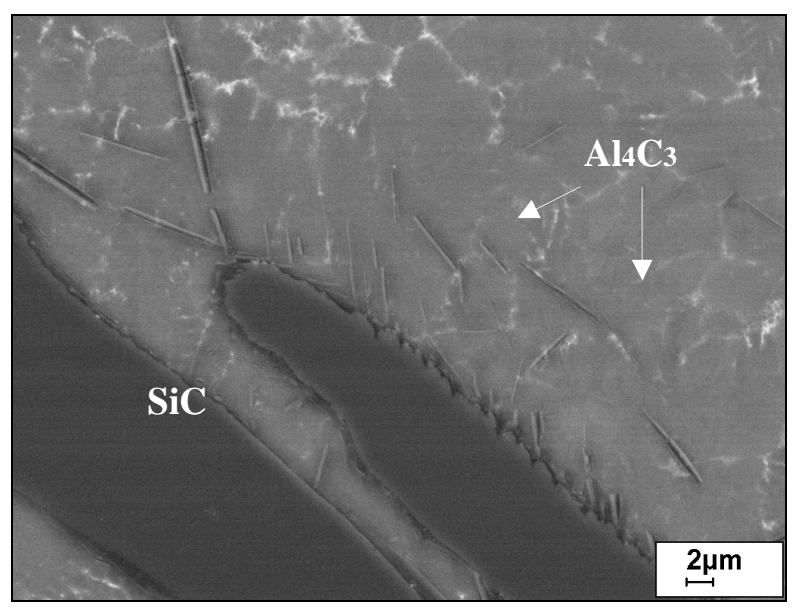

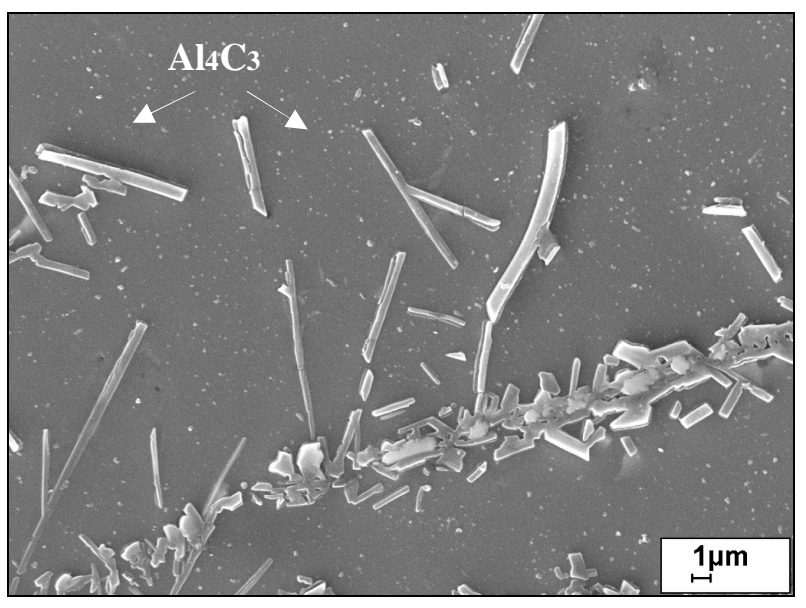

$b$

Fig. 4. Microstructure of surface layer of aluminium alloy modified by SiC powder (a), shapes of grains of aluminium carbide $(b)$

The amount of $\mathrm{Al}_{4} \mathrm{C}_{3}$ carbide formed in the interaction with $\mathrm{SiC}$ particles strongly depends on the temperature in the melted zone. In upper layers of the re-melted zone (Fig. 5, $a$ ), there were discovered more $\mathrm{Al}_{4} \mathrm{C}_{3}$ particles than in lower layers where the temperature was lower.

The formation of $\mathrm{Al}_{4} \mathrm{C}_{3}$ is accompanied also by release of $\mathrm{Si}$ (Fig. 5, b). Thus eutectic domains of $\mathrm{Si}-\mathrm{Al}$ are found between plates of aluminium carbide. In the interaction of $\mathrm{Al}$ melt with $\mathrm{SiC}$ particles, plates of $\mathrm{Al}_{4} \mathrm{C}_{3}$ carbide are formed, they grow, mainly perpendicular to the orientation of the $\mathrm{SiC}$ crystal, in the direction of the melt. Besides, aluminium carbide also grows around a $\mathrm{SiC}$ particle; the lengths of plates is up to $0.3-3 \mu \mathrm{m}$.

It is obvious that the interaction of $\mathrm{SiC}$ with $\mathrm{Al}$ melt could ensure strong connection between $\mathrm{SiC}$ particles and the aluminium alloy of the matrix. In majority of cases, the plates are parallel to one another, being independent of the curvature of the $\mathrm{SiC}$ surface.

The microhardness of silicium carbide considerably exceeds the microhardness of the basis, but carbide grains are prone to brittle fracture for example, under indentation of diamond pyramid into them (Fig. 6).

The influence of structure of superficially reinforced by solid SiC particles AD35 and B95 aluminium alloys on their wear resistances has been investigated [4]. The determination of abrasive wear 


\section{Mykhaylo Student, Hanna Pokhmurska, Khrystyna Zadorozhna, Andrii Dzyubyk, Ivan Khomych}

resistance in friction by a rigidly fixed abrasive has indicated (Table 2) that the resistance to abrasive wear of the initial alloy under the accepted regimes of their thermal treating is by $40 \%$ greater for AD35 than that for B95.

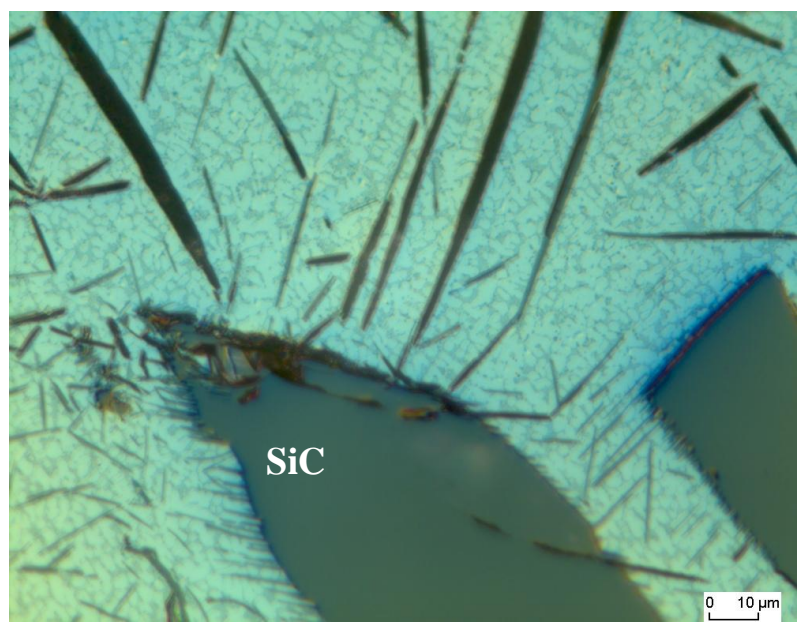

$a$

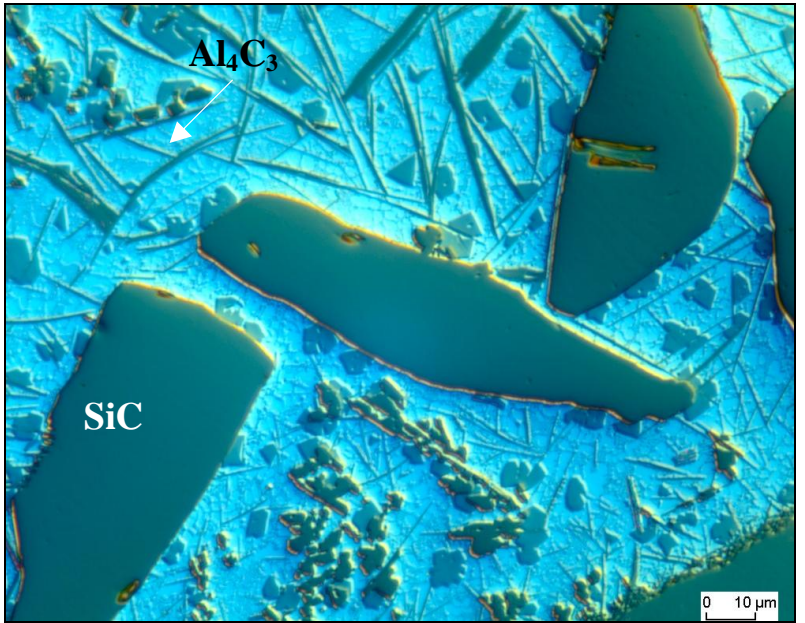

$b$

Fig. 5. Microstructure of modified layer with $\mathrm{Al}_{4} \mathrm{C}_{3}$ plates in re-melted matrix (a) and release of $\mathrm{Al}_{4} \mathrm{C}_{3}$ and of silicium grains (b)

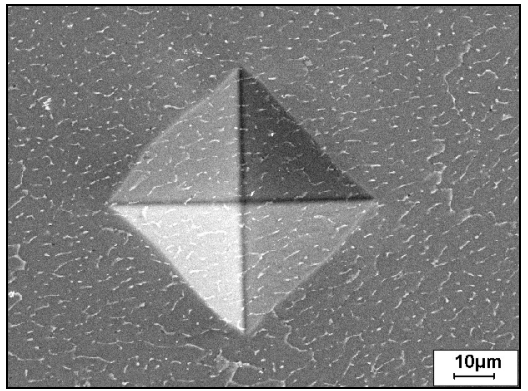

$a$

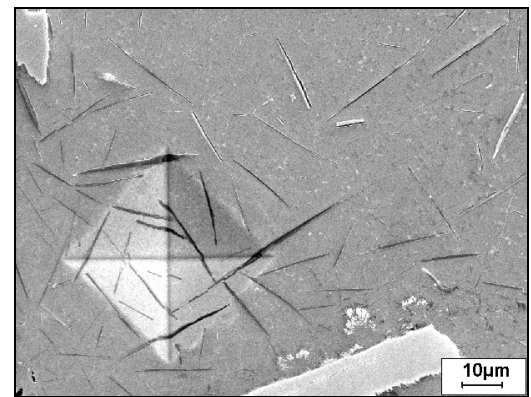

$b$

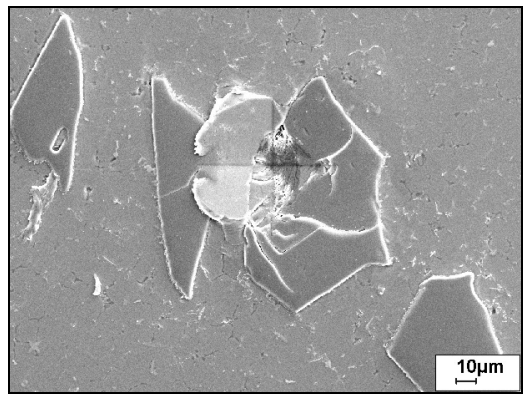

$c$

Fig. 6. General appearance of indentations of diamond pyramid of microhardness tester in different places of alloy: non-modified layer (a), re-melted alloy (b), character of fracture of SiC grains (c)

Table 2

Wear resistance of aluminium alloys in friction by abrasive wheel (friction path $1500 \mathrm{~m}$ )

\begin{tabular}{|c|c|c|c|c|}
\hline \multirow{2}{*}{ Alloy } & \multirow{2}{*}{ Direction of friction } & \multirow{2}{*}{ Mass loss, $\mathrm{g}$} & \multicolumn{2}{|c|}{ Conditions of reinforcement of alloys } \\
\hline & & & Substrate heating, ${ }^{\circ} \mathrm{C}$ & Rate of scanning, $\mathrm{m} / \mathrm{min}$ \\
\hline AD35 & Basis & 0.8880 & & \\
\hline \multirow[t]{2}{*}{ AD35 (SiC) } & Along & 0.0109 & \multirow{2}{*}{170} & \multirow{2}{*}{1.5} \\
\hline & Across & 0.0123 & & \\
\hline \multirow[t]{2}{*}{ AD35 (SiC) } & Along & 0.0142 & \multirow{2}{*}{170} & \multirow{2}{*}{1.0} \\
\hline & Across & 0.0197 & & \\
\hline B95 & Basis & 1.3995 & & \\
\hline \multirow[t]{2}{*}{ B95 (SiC) } & Along & 0.0216 & \multirow{2}{*}{260} & \multirow{2}{*}{1.0} \\
\hline & Across & 0.0153 & & \\
\hline \multirow[t]{2}{*}{$\mathrm{B} 95(\mathrm{SiC})$} & Along & 0.0362 & \multirow{2}{*}{ no heating } & \multirow{2}{*}{1.5} \\
\hline & Across & 0.0546 & & \\
\hline \multirow[t]{2}{*}{ B95(SiC) } & Along & 0.0516 & \multirow{2}{*}{230} & \multirow{2}{*}{1.0} \\
\hline & Across & 0.0268 & & \\
\hline
\end{tabular}


The reinforcement of surface by $\mathrm{SiC}$ particles causes essential improvement of wear resistance of the alloy. Thus laser-reinforcement of surface of AD35 alloy increases its wear resistance from 40 to 80 times and that of B95 alloy from 30 to 90 times.

Such a high wear resistance is ensured by $\mathrm{SiC}$ particles which are well bonded to the base material through $\mathrm{Al}_{4} \mathrm{C}_{3}$ carbide and are of considerably greater microhardness than that of $\mathrm{Al}_{2} \mathrm{O}_{3}(360 \mathrm{MPa}$ and $200 \mathrm{MPa}$, respectively.

Since the laser-modified layer is of pronounced structural anisotropy, the testing was conducted both along and across the tracks of the modified surface layer (Fig. 7). It is found that during the friction of a reinforced surface of the alloy by an abrasive wheel there is practically no adherence of aluminium and of weared articles on the working part of it; only in the case when between reinforced track there becomes bare a region which is free of interspersed $\mathrm{SiC}$ particles small sticking of material of the aluminium alloy is observed [10].
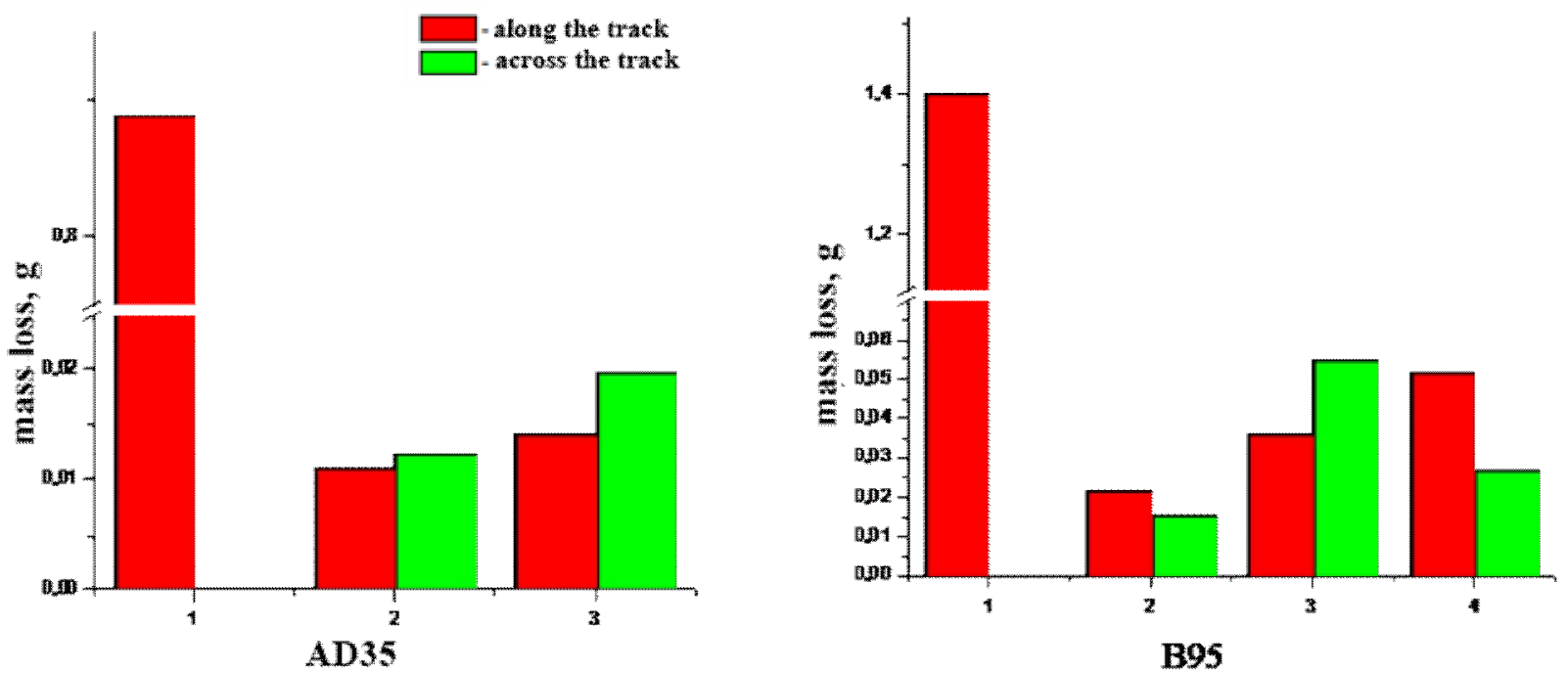

Fig. 7. Losses of mass of specimens of aluminium alloys in friction by abrasive wheel (Designations correspond to those of Table 1)

During the friction along tracks of reinforced surface of the alloy, the resistance is higher approximately by $25-30 \%$ than in the friction across.

The peripheral zones of fused tracks cool faster, and the time for interaction of $\mathrm{SiC}$ and $\mathrm{Al}$ is less; there form less number of needle crystals of aluminium carbide in them, and therefore, it is easier to tear them from the body by an abrasive wheel. In some cases, the wear resistance in the direction along tracks of laser-fusing is less than that of across the tracks. It is obvious that this is due to the fact that $\mathrm{SiC}$ particles are non-uniformly distributed both over the surface of a specimen and along the depth of it.

With the increase of the speed of movement of the laser-beam from 0.1 to $1.5 \mathrm{~m} / \mathrm{s}$, the wear resistance of the modified layer of AD35 alloy insufficiently increases. It has been found that the preliminary heating of the specimen to $170{ }^{\circ} \mathrm{C}$ leads to $2-3$ times increase in its wear resistance. It is obvious that during a preliminary heating there takes place a more active interaction between $\mathrm{SiC}$ particles and melt of $\mathrm{Al}$, and as a consequence, $\mathrm{SiC}$ particles are better connected to the matrix - aluminium alloy -, the number of them and depth of disposition are greater.

It is shown that the reinforcement of surfaces of alloys by $\mathrm{SiC}$ particles makes the wear resistance of the surface alloys by several tens greater (Table 1 ).

In wear of surfaces of aluminium alloys by a rubber wheel with sand, the effectiveness of lasermodification sharply decreases; alongside with this, there is observed insufficient influence of regimes of the surface modifying on the resistance of the surface to abrasive wear. Depending on the regimes of treatment, the wear resistance increases only by $15-20 \%$ as compared to non-modified surface, that is 
within the accuracy of the technique given. The low wear resistance is caused by the fact that during the friction the sand gets into a gap between the rubber wheel and the metal; the sand travels not through vertices of solid particles, like it is in friction by abrasive wheel, but between them, and the sand easily cuts the soft aluminium matrix making solid SiC grains bare; after this, grains are easily teared-off by the rubber wheel.

In dry friction, a wheel made of WX15 (C-0.95-1.05\%; $\mathrm{Si}-0.17-0.37 \% ; \mathrm{Mn}-0.2-0.4 \% ; \mathrm{Ni} \leq 0.3 \%$; $\mathrm{Cr}-1.3-1.65 \%)$ steel whose diameter and width were $40 \mathrm{~mm}$ and $10 \mathrm{~mm}$, respectively, was used as a counter-body, the steel had been hardened to 60 HRC. The size of the working surfaces of the specimens was of $30 \mathrm{X} 18 \mathrm{X} 8 \mathrm{~mm}$, their interaction with the counter-body was through linear contact. Before the testing, the working surface had been grinded. The specimen was pressed to the counter-body with a force of $1.5 \mathrm{~kg}$. The speed of friction amounted to $0.67 \mathrm{~m} / \mathrm{min}$, and the test duration was 1 hour.

It is shown (Table 3) that laser-reinforcement of surfaces of alloys by $\mathrm{SiC}$ particles increases the wear resistance of B95 alloy by 35-50\%, and for AD35 alloy there takes place 2-5 times increase.

Table 3

Wear resistance of alloys in dry friction along reinforced tracks (load: $1.5 \mathrm{~kg}$; duration of friction: 1 hour)

\begin{tabular}{|l|c|c|c|c|}
\hline \multirow{2}{*}{ № } & \multirow{2}{*}{ Alloys } & \multirow{2}{*}{ Mass loss, $\mathrm{g}$} & \multicolumn{2}{|c|}{ Conditions of surface reinforcing } \\
\cline { 4 - 5 } & & & Substrate heating, ${ }^{\circ} \mathrm{C}$ & Speed of scanning, $\mathrm{m} / \mathrm{min}$ \\
\hline 1 & $\mathrm{~B} 95$ & 0.0048 & base & 1.0 \\
\hline 2 & $\mathrm{~B} 95(\mathrm{SiC})$ & 0.0036 & 260 & 1.5 \\
\hline 3 & $\mathrm{~B} 95(\mathrm{SiC})$ & 0.0036 & no heating & 1.0 \\
\hline 4 & $\mathrm{~B} 95(\mathrm{SiC})$ & 0.0033 & 230 & 1.5 \\
\hline 5 & $\mathrm{AD} 35$ & 0.0039 & base & 1.0 \\
\hline 6 & $\mathrm{AD} 35(\mathrm{SiC})$ & 0.0008 & 170 & 170 \\
\hline 7 & $\mathrm{AD} 35(\mathrm{SiC})$ & 0.0018 & & \\
\hline
\end{tabular}

The maximal values of wear resistance have been obtained in the case of surface modification with heating to $170{ }^{\circ} \mathrm{C}$ and the speed of displacement of laser beam of $1.5 \mathrm{~m} / \mathrm{min}$. Under such a regime of treatment, there is achieved high concentration of particles of silicium carbide in the surface layer of alloy, but the depth of their position is inconsiderable. During the friction, surface layers of alloy are heated to a temperature which is sufficient for formation of oxide films on their surfaces.

\section{Conclusions}

1. It has been is found that in laser-reinforcement of surfaces of aluminium alloys by dispersed particles of $\mathrm{SiC}$ silicium carbide, there takes place partial dissolution of $\mathrm{SiC}$ in the matrix with formation of needle-like $\mathrm{Al}_{4} \mathrm{C}_{3}$ aluminium carbide.

2. In friction by rigidly fixed particles, the wear resistance of laser-modified SiC layers on aluminium alloys is from 30 to 75 times greater than that of non-modified ones.

3. In wearing by loose particles, the difference between the wear resistance of modified surface and that of non-modified one is inconsiderable, it is determined only by the wear of matrix alloys.

4. The reinforcement of surface of B95 aluminium alloy by $\mathrm{SiC}$ particles increases its wear resistance 1.7-1.9 times in dry friction and insignificantly influences the wear intensity of the ball. Such a treatment of aluminium alloys turned out to be low-efficient means of their protection against wear by a loose abrasive.

\section{References}

[1] V. M. Korzh, et al., Nanesennia pokryttia [Coating]. Kyiv, Ukraine: Aristei Publ., 2005. [In Ukrainian].

[2] K. A. Yushchenko, et al., Inzheneriia poverkhni [Surface engineering]. Kyiv, Ukraine: Naukova Dumka Publ., 2007. [In Ukrainian]. 
[3] H. Pokhmurska, M. Student, and V. Pokhmurskyi, Hazotermichni pokryttia [Gas-thermal coatings]. Lviv, Ukraine: Prostir-M Publ., 2017. [In Ukrainian].

[4] T. Hoenig, et al., "Verfahrensentwicklung zum Laserdispergieren von Si-Hartstoffen in Aluminiumlegirungen zum partiellen Verschleisschutz" ["Process development for the laser dispersion of Si-hard materials in aluminum alloys for partial wear protection"], Schriftenreihe Werkstoffe und werkstofftechnische Anwendungen, vol. 022, pp. 91-96, 2005. [in German].

[5] A. A. Vedenov, and G. G. Gladush, Fizicheskie protsessy pri lazernoi obrabotke materialov [Physical processes in laser processing of materials]. Moscow, Russia: Energoatomizdat Publ., 1985. [in Russian].

[6] V. P. Veiko, and M. N. Libenson, Lazernaia obrabotka [Laser processing]. Leningrad, Russia: Lenizdat Publ., 1973. [in Russian].

[7] K.-J. Mattes, and E. Seliga, Schweßen und Schneiden mit Lasern, Professur Schweßtechnik, TU Chemnitz [Welding and cutting with lasers, Professorship of welding technology, TU Chemnitz]. 1998. [in German].

[8] M. M. Khrushchov, and M. A. Babichev, Abrazivnoe iznashivanie [Abrasion wear]. Moscow, Russia: Nauka Publ., 1970. [in Russian].

[9] Obespechenie iznosostoikosti izdelii Metod ispytaniia materialov na iznosostoikost pri trenii o nezhestko zakreplennye abrazivnye chastitsy [Provision of wear resistance of products. Method for testing materials for abrasion resistance in the presence of friction abrasive particles], GOST 23.208-79, 1979. [in Russian].

[10] Kh. R. Zadorozhna, et al., "Znosostiikist lazerno modyfikovanykh karbidom kremniiu poverkhnevykh shariv aliuminiievykh splaviv" ["Abrasion resistance of laser-modified silicon carbide surface layers of aluminum alloys"], in Proceedings of 11th Scientific and Practical Conference of students, postgraduates and young scientists "Improving the reliability of machinery and equipment", Kropyvnytskyi, Ukraine, April 20-21, 2017, pp. 40-43. [in Ukrainian]. 